\title{
SIMPLE AND RAPID GENETIC IDENTIFICATION OF LEGIONELLA SPECIES WITH PHOTOBIOTIN-LABELED DNA
}

\author{
TAKAYUKI EZAKI, SURANG DEJSIRILERT, ${ }^{*}$ HIROYUKI YAMAMOTO, \\ NORIKO TAKEUCHI, SHULIN LIU, AND EIKO YABUUCHI \\ Department of Microbiology, Gifu University School of Medicine, \\ 40 Tsukasa-machi, Gifu 500, Japan \\ * National Institute of Health, Division of Clinical Pathology, \\ Department of Medical Science, Nonthaburins 11000, Thailand
}

(Received April 6, 1988)

\begin{abstract}
Rapid and simple dot hybridization was designed and developed for the identification of Legionella species.

DNAs from 18 type strains of Legionella species were quantitatively spotted on nitrocellulose filters and kept in a desiccation chamber. When an organism was suspected of belonging to the Genus Legionella, the DNA of the isolate was quickly extracted from a single colony, or $1 \mathrm{ml}$ of the bacterial suspension that matched the turbidity of the No. 2 McFarland standard. The DNA was labeled with photobiotin within $15 \mathrm{~min}$ and a dot hybridization experiment was carried out between the labeled DNA of the unknown organism and the reference DNAs of 18 type strains of Legionella species. Hybridization was stopped within $4 \mathrm{hr}$. Hybridized spots were visualized with alkaline-phosphatase color detection method. The reaction for the color detection was stopped within $30 \mathrm{~min}$ and the color intensity of the hybridized spots was measured with a color graphic analyzer to determine the strongest spot.

Among about 500 environmental strains identified as legionellae at the genus level, 20 strains were serologically unidentified. They were hippuratepositive legionellae but did not react to any antisera of hippurate-positive Legionella species. These strains were finally identified as L. pneumophila by our simplified colorimetric dot-hybridization method.
\end{abstract}

The genus Legionella currently includes 23 species and their biochemical differentiation is not possible by conventional biochemical tests because the species were established on the basis of their DNA-DNA homologies value (l). Species-

Address reprint requests to: Dr. T. Ezaki, Department of Microbiology, Gifu University School of Medicine, 40 Tsukasa-machi, Gifu 500, Japan. 
specific antisera have been developed for several legionellae species but only a few antisera are commercially available. Many environmental strains of legionellae sent to our laboratory did not react with the commercial antisera and some strains cross reacted with several antisera. To identify these environmental isolates, quantitative DNA-DNA hybridization experiments were required. However, the current DNA-DNA hybridization method is demanding and needs radioisotopes for labeling DNA. We wished to develop a simple and rapid DNA-DNA hybridization for the routine identification of these legionellae strains.

Forster et al.(2) and Renz and Kurz(3) developed a very simple DNA labeling method. The former developed a photobiotin method and the latter a polyethylenimine-bound peroxidase method. The photobiotin-bound DNA under visible light within a few minutes, and then the labeling procedure became quite simple. But after hybridization, the biotinylated DNA fragments were bound to streptavidin-alkaline phosphatase to visualize the hybridized fragments. The method developed by Renz was simpler than the photobiotin method. Peroxidase was bound to a DNA probe prior to hybridization. After hybridization, the hybridized spots were detected simply by adding substrates. However, quantitative analysis of the DNA-bound peroxidase was not easy because the enzyme reaction of peroxidase was very fast and was completed within a few minutes. We then selected the photobiotin-alkaline phosphatase method to visualize hybridized spots, because the enzyme reaction of alkaline phosphatase was slow and the color intensity of the hybridized spots could be easily quantified.

It is not necessary to purify the DNA for photobiotin labeling. This fact greatly limited the amount of bacteria needed to extract DNA. One milliliter of bacterial suspension of McFarland turbidity standard No. 2 was sufficient to extract DNA for labeling and to run several DNA-DNA hybridization experiments. This amount of bacteria were usually obtained from a single colony. The successful application of this method for the routine identification of Legionella species is presented.

\section{MATERIALS AND METHODS}

Bacterial strains. Twenty three reference strains of Legionella species are listed in Table 1, and the 20 environmental isolates of Legionella species in Table 2. These environmental strains were isolated from water in cooling-towers in various geographical areas in Japan. They were hippurate positive but did not react with any commercially available antisera against L. pneumophila through serogroups 1 to 6 (Denka Seiken Co., Ltd., Tokyo).

Reference DNA preparation. DNAs of type strains were prepared by standard Marmur's procedure with minor modifications (4). Heat denatured DNA concentration of each type strain was adjusted to $100 \mu \mathrm{g} / \mathrm{ml}$ in twofold concentrated saline-trisodium-citrate $(2 \times \mathrm{SSC})$ buffer, $\mathrm{pH} 8.0$ and serially diluted to prepare four different solutions $(100,50,25$, and $12.5 \mu \mathrm{g} / \mathrm{ml})$. Two microliters of each DNA 
Table 1. Reference Legionella strains.

\begin{tabular}{|c|c|c|c|c|c|}
\hline & Species & $\begin{array}{c}\text { GIFU } \\
\text { strain No. }\end{array}$ & Status & Serogroup & $\begin{array}{l}\text { Other strain } \\
\text { designation }\end{array}$ \\
\hline 1 & L. anisa & 11198 & Type strain & & WA-316-C3 \\
\hline 2 & L. bozemanii & 9140 & Type strain & 1 & ATCC 33217 \\
\hline 3 & L. bozemanii & 10739 & & 2 & CDC Toronto 3 \\
\hline 4 & L. cherrii & 10742 & Type strain & & CDC ORW \\
\hline 5 & L. dumoffii & 9244 & Type strain & & ATCC 33343 \\
\hline 6 & L. feeleii & 10063 & Type strain & 1 & CDC WO-44C \\
\hline 7 & L. feeleii & 10744 & & 2 & CDC 691-WI-H \\
\hline 8 & L. gormanii & 9142 & Type strain & & ATCC 33297 \\
\hline 9 & L. hackeliae & 10740 & Type strain & & CDC Lansing 2 \\
\hline 10 & L. jamestowniensis & 10741 & Type strain & & CDC JA-26-G1-E2 \\
\hline 11 & L. jordanis & 3193 & Type strain & & ATCC 33623 \\
\hline 12 & L. longbeachae & 9245 & Type strain & & ATCC 33462 \\
\hline 13 & L. maceachernii & 10745 & Type strain & & CDC PX-1-G2-E2 \\
\hline 14 & L. micdadei & 9141 & Type strain & & ATCC 33218 \\
\hline 15 & L. oakridgensis & 10061 & Type strain & & CDC OR 10 \\
\hline 16 & L. rubrilucens & 10743 & Type strain & & CDC WA-270A-C2 \\
\hline 17 & L. pneumophila & 9134 & Type strain & 1 & ATCC 33152 \\
\hline 18 & L. pneumophila & 9137 & & 3 & ATCC 33155 \\
\hline 19 & L. pneumophila & 9246 & & 4 & ATCC 33156 \\
\hline 20 & L. pneumophila & 10065 & & 8 & CDC Concord 3 \\
\hline 21 & L. sainthelensii & 10392 & Type strain & & ATCC 35248 \\
\hline 22 & L. spiritensis & 11199 & Type strain & & CDC MSH 9 \\
\hline 23 & L. wadsworthii & 10062 & Type strain & & CDC 81-716 \\
\hline
\end{tabular}

Table 2. Twenty hippurate-positive legionellae ${ }^{a}$ isolated from water in cooling towers.

\begin{tabular}{cc}
\hline Geographical area & \multicolumn{1}{c}{ GIFU stock No. } \\
\hline Gifu & $10223,10224,10225,10226,10238,10240,10244$ \\
Osaka & $10227,10228,10229,10230,10231$ \\
Aichi & $10232,10233,10234,10235,10236$ \\
Tokyo & $10258,10261,10264$ \\
\hline
\end{tabular}

a All strains grew on a BCYE medium but not on a blood agar plate. They required cysteine, produced catalase and dark yellow fluorescence. They did not react with the antisera of L. pneumophila through types 1 to 6 .

solution was spotted on a nitrocellulose filter (Millipore HATY; Nihon Millipore, Yonezawa, Japan) and stocked at room temperature for a few weeks.

Small-scale DNA extraction for labeling. The organisms in Table 2 were harvested from BCYE agar plate (Eiken Kagaku, Tokyo, Japan) and suspended in $1 \mathrm{ml}$ of $50 \mathrm{~mm}$ ethylenediamine tetraacetic acid (EDTA), pH 8.0. The bacterial suspension was then adjusted to match the turbidity of a McFarland No. 2 standard, transferred to an Eppendorf tube and centrifuged at 15,000 rpm for $30 \mathrm{sec}$ in a microcentrifuge (KM-15200, Kubota Corp., Tokyo). The sedimented bacteria 
were resuspended in $200 \mu \mathrm{l}$ of $50 \mathrm{~mm}$ EDTA (pH 8.0) and vortexed for a few seconds. The suspension was mixed with $50 \mu \mathrm{g}$ of lysozyme $(5 \mathrm{mg} / \mathrm{ml})$ and incubated at $37^{\circ} \mathrm{C}$ for $15 \mathrm{~min}$. Then, $50 \mu \mathrm{l}$ of $20 \%$ sodium dodecyl sulfate (SDS) solution was added to the mixture, which was immediately placed in a $60^{\circ} \mathrm{C}$ water bath and incubated for $10 \mathrm{~min}$. After the addition of $500 \mu \mathrm{l}$ of phenol-chloroform-isoamylalcohol $(25: 24: 1)$, the mixture was vortexed for $20 \mathrm{sec}$. It was then centrifuged at $15,000 \mathrm{rpm}$ for $5 \mathrm{~min}$ and the supernatant was transferred into a new Eppendorf tube. After adding $20 \mu \mathrm{l}$ of $5 \mathrm{M} \mathrm{NaCl}$, two volumes of ethanol were mixed with the supernatant to precipitate DNA. After centrifugation, the sedimented DNA was resuspended in $100 \mu \mathrm{l}$ of saline-EDTA buffer $(0.15 \mathrm{M} \mathrm{NaCl}, 0.1 \mathrm{M}$ sodium EDTA, pH 8.0). Ten microliters of $2 \mathrm{mg} / \mathrm{ml} \mathrm{RNase} \mathrm{(Sigma} \mathrm{Chemical} \mathrm{Co.,} \mathrm{St.} \mathrm{Louis,}$ MO) was added to the suspension and kept at $37^{\circ} \mathrm{C}$ for $20 \mathrm{~min}$. Ten microliters of $2 \mathrm{mg} / \mathrm{ml}$ Actinase (Kaken-Kagaku Co., Tokyo) was then added to the mixture and incubated at $37^{\circ} \mathrm{C}$ for $20 \mathrm{~min}$. The mixture was then extracted with $200 \mu \mathrm{l}$ of chloroform-iso-amylalcohol $(24: 1)$ and centrifuged at $15,000 \mathrm{rpm}$ for $3 \mathrm{~min}$ to remove proteins. The upper layer was transferred into a new Eppendorf tube and the DNA was precipitated with 2 volumes of ethanol then centrifuged at $15,000 \mathrm{rpm}$ for $3 \mathrm{~min}$. The supernatant was discarded and the sedimented DNA was washed with $70 \%$ ethanol and dried at room temperature. The DNA was finally dissolved into $20 \mu$ of $0.1 \mathrm{~mm}$ EDTA buffer, $\mathrm{pH} 8.0$.

The DNA concentrations prepared by the small-scale method were determined by the modified diphenylamine method. Briefly, $30 \mu \mathrm{l}$ of DNA solution was placed in a microtube and $30 \mu \mathrm{l}$ of $20 \%$ perchloric acid was added. Then, $60 \mu \mathrm{l}$ of gracial acetic acid containing $4 \%$ diphenylamine was added to the tube. Ten microliters of a $0.16 \%$ solution of acetaldehyde was added to the tube and heated at $100^{\circ} \mathrm{C}$ for $5 \mathrm{~min}$. Absorbance at 595 and $700 \mathrm{~nm}$ was read by an EIA reader (BioRad 2550) and the value was compared with pure DNA standards (salmon sperm DNA; Sigma Chemical Co., St. Louis, MO).

Labeling of DNA with photobiotin. Five micrograms of heat denatured DNA solution in $0.01 \mathrm{~mm}$ EDTA was mixed with $5 \mu$ l of photobiotin (Vector Labo. Inc., CA). The mixture was cooled in an ice-water bath and then irradiated with a sunlamp $(500 \mathrm{~W})$ at a distance of $10 \mathrm{~cm}$ for $15 \mathrm{~min}$. After labeling, the total volume of the reaction mixture was increased up to $100 \mu \mathrm{l}$ by adding $0.1 \mathrm{M}$ tris- $\mathrm{HCl}$ buffer, $\mathrm{pH} 9.0$. Then, $100 \mu \mathrm{l}$ of 2 -butanol was added to the tube. The mixture was thoroughly mixed and centrifuged. The upper phase, 2-butanol, was discarded. This 2-butanol extraction procedure was repeated twice in order to remove free photobiotin. The lower phase, containing biotinylated DNA was used immediately for the hybridization experiments.

Quantitative dot hybridization. The hybridization experiments followed the procedure described by LEARY et al. (5). Briefly, the labeled and denatured DNA ( $500 \mathrm{ng}$ to $5 \mu \mathrm{g}$ ) was prepared for one hybridization experiment with $100 \mathrm{~cm}^{2}$ filter size. The filter was completely soaked in a prehybridization mixture for $1 \mathrm{hr}$ at $42^{\circ} \mathrm{C}$ and then in a hybridization mixture from 4 to $6 \mathrm{hr}$ at the same temperature. The 
final concentration of formamide in the hybridization mixture was $45 \%$.

Detection of biotinylated DNA on a nitrocellulose filter. The hybridized filter was washed two times with $100 \mathrm{ml}$ of $2 \times \mathrm{SSC}$ buffer with $0.1 \% \mathrm{SDS}$ and once with $100 \mathrm{ml}$ of $2 \times \mathrm{SSC}$ buffer. The washed filter was dipped in buffer $1(0.1 \mathrm{M}$ tris- $\mathrm{HCl}$, $0.1 \mathrm{M} \mathrm{NaCl}, 2 \mathrm{~mm} \mathrm{MgCl}_{2}, 0.05 \%$ Triton-X-100, pH 7.5) with $3 \%$ bovine serum albumin at $42^{\circ} \mathrm{C}$ for $20 \mathrm{~min}$. The filter was transferred into $10 \mathrm{ml}$ of buffer 1 containing 10 units of streptavidin-alkaline phosphatase (ZYMED, San Francisco, CA) and incubated at $37^{\circ} \mathrm{C}$ for $10 \mathrm{~min}$. Then the filter was washed twice, with $100 \mathrm{ml}$ of buffer 1 . The hybridized spots were visualiżed by placing the filter in $10 \mathrm{ml}$ of an alkaline buffer ( $0.1 \mathrm{M}$ tris- $\left.\mathrm{HCl}, 0.1 \mathrm{M} \mathrm{NaCl}, 50 \mathrm{mM} \mathrm{MgCl}_{2}, \mathrm{pH} 9.5\right)$ containing $2.5 \mathrm{mg}$ of nitro-blue-tetrazolium and $1.25 \mathrm{mg}$ of 5-bromo-4-chloro-3-indolyl-phosphate. When the strongest DNA spot became clearly visible, the alkaline buffer was discarded and washed with distilled water to stop the reaction. The color intensity of the hybridized spots were quantitatively measured with a color graphic analyzer (TEF Corp. Ltd., Tokyo).

\section{RESULTS}

\section{Simplified DNA extraction}

An adequate amount of the DNAs of the 23 reference strains listed in Table 1 and the 20 cooling tower isolates listed in Table 2 could be extracted from $1 \mathrm{ml}$ of each bacterial suspension with a turbidity that matched McFarland No. 2 standard. The total amount of DNA obtained from these strains was usually 5-15 $\mu \mathrm{g}$.

\section{Amount of biotin-labeled DNA}

Five micrograms of DNA was labeled at one time. For one dot hybridization experiment with a $100 \mathrm{~cm}^{2}$ filter size, 0.5 to $5 \mu \mathrm{g}$ of labeled DNA was used. The incubation for the enzyme reaction was usually stopped within $30 \mathrm{~min}$. When $500 \mathrm{ng}$ of the labeled DNA of the type strain of Legionella pneumophila GIFU 9134 was used for one hybridization, four DNA spots of the same L. pneumophila strain hybridized, and the reference DNA spots of other species were not detected as clearly hybridized ones, as shown in Fig. 1.

The DNAs from serogroup 3 (GIFU 9137), 4 (GIFU 9246) and 8 (GIFU 10065) strains of $L$. pneumophila clearly hybridized with those of the type strain of $L$. pneumophila (serogroup 1) even at $25 \mathrm{ng}$, but not with other species even at $200 \mathrm{ng}$ (Fig. 1).

When $5 \mu \mathrm{g}$ of labeled DNA was used, the number of cross-hybridized spots increased, but the labeled DNA hybridized most strongly with its own DNA as shown in Fig. 2.

The incubation time for the enzyme reaction affected the results. When the enzyme reaction was stopped within $15 \mathrm{~min}$, only homologous DNA spots were visualized. However, higher DNA spots ( $200 \mathrm{ng}$ ) of other organisms became visible when the reaction was stopped after $2 \mathrm{hr}$, but they were clearly differentiated from 


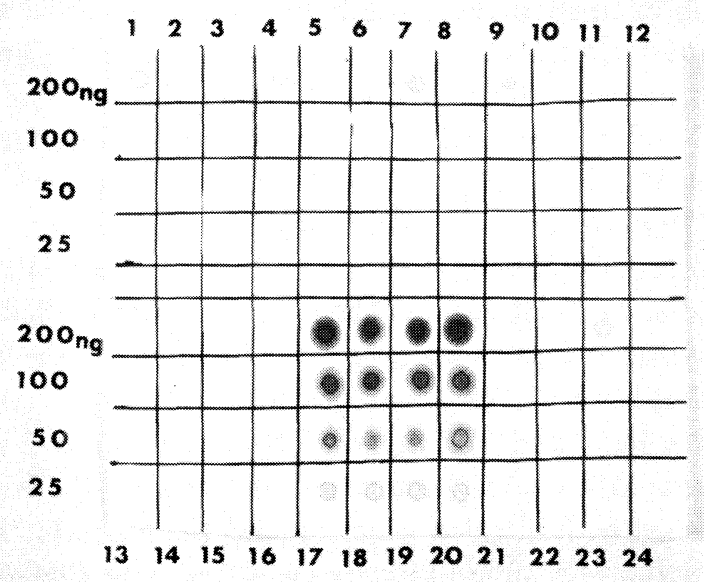
species.

Fig. 1. DNA-DNA dot hybridization between L. pneumophila and other Legionella

L. pneumophila GIFU $9134^{\mathrm{T}}$ was labeled and $500 \mathrm{ng}$ of the labeled DNA was used to hybridize with $100 \mathrm{~cm}^{2}$ filter size. The amount of each DNA is indicated to the left of each horizontal lane. Number from 1 to 23 are in the same order as listed in Table 1. No. 24 is calf thymus DNA. The enzyme reaction was stopped within $30 \mathrm{~min}$ after adding substrates.

homologous spots with a color graphic analyzer (Fig. 3).

Practical identification of environmental strains of legionellae by quantitative dot hybridization

DNAs from 20 hippurate-positive and serologically unidentified environmental isolates hybridized with that of the type strain of $L$. pneumophila but not with the DNA of the hippurate-positive DNAs of the other two species, L. feeleii and $L$. spiritensis (Fig. 4).

\section{DISCUSSION}

A specific DNA fragment of Legionella species is in the detection of legionellae $(6,7)$. This probe is complementary to the rRNA of Legionella species so it can be used to detect most Legionella at the generic level. But this probe is labeled with ${ }^{125}$ I so it is not easy to use it in many clinical laboratories in Japan. Also, it cannot be used to identify individual Legionella species.

Currently, most microbiology laboratories use a serologic identification system, because the biochemical characterization of Legionella species is practically ineffective. However, few commercially available antisera for Legionella species are available and many environmental isolates are not identified at the species level. The environmental isolates used in this study were not definitely identified before the hybridization was performed because they were agglutinated by none of the 


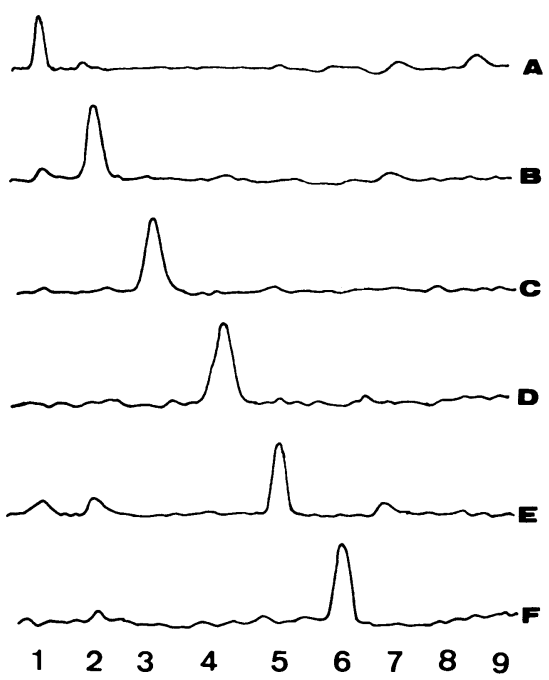

Fig. 2. Quantification of hybridized spots with a color graphic analyzer.

A $50 \mathrm{ng}$ spot of each reference strain DNA was quantified with a color graphic analyzer. The enzyme reaction was stopped within $30 \mathrm{~min}$.

Horizontal lane (labeled strain): A, L. bozemanii GIFU 9141 ${ }^{\mathrm{T}}$; B, L. dumoffii GIFU 9244 ${ }^{\mathrm{T}}$; C, L. pneumophila GIFU $9134^{\mathrm{T}}$; D, L. feeleii GIFU $10063^{\mathrm{T}}$; E, L. gormanii GIFU $9142^{\mathrm{T}}$; F, L. spiritensis GIFU $11199^{\mathrm{T}}$.

Order of spotted DNAs: 1, L. bozemanii GIFU 9141; 2, L. dumoffii GIFU 9244; 3, L. pneumophila GIFU 9134 $;$; , L. feeleii GIFU 10063 ${ }^{\mathrm{T}}$; 5, L. gormanii GIFU 9142 ${ }^{\mathrm{T}} ; 6$, L.

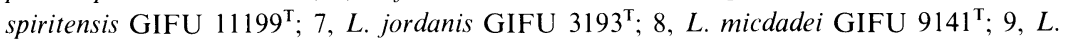
cherrii GIFU $10742^{\mathrm{T}}$.

commercially available antisera for Legionella pneumophila serogroups 1 to 6 . Furthermore antisera for $L$. feeleii and L. spiritensis, hippurate-positive species other than L. pneumophila, are not available.

Through the experiment presented here, total chromosomal DNA was sufficient to identify Legionella species of medical importance under carefully controlled experimental conditions. DNA spots of $200 \mathrm{ng}$ sometimes gave non-specific reaction (data not shown) under our experimental conditions. In that case, the filter was analyzed with a color graphic analyzer.

In general, homology values of DNA-DNA hybridization among independent species are usually less than $70 \%$. In our preliminary experiments, this quantitative dot-hybridization method could differentiate closely related organisms when the homology value between them was less than $60 \%$.

Fortunately, homology values among the type strains of the genus Legionella are less than $65 \%(1)$, so most Legionella species may be differentiated by this dot hybridization.

A color graphic analyzer was an effective tool to quantify hybridized spots. Thus, cross-hybridized spots were easily compared. Still this is an expensive set-up 

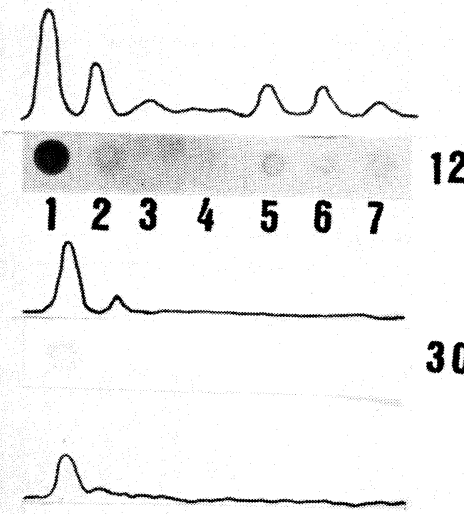

120

30

\section{$15 \mathrm{M}$}

Fig. 3. Effect of incubation time for the enzyme reaction on the color intensity of hybridized spots.

The DNA of L. pneumophila GIFU $9134^{\mathrm{T}}$ (500 ng) was labeled and hybridized at $42^{\circ} \mathrm{C}$ for $6 \mathrm{hr}$. Two hundred nanograms of the DNA spots was quantified with a color graphic analyzer, at different times after adding the substrates. The reaction was stopped $15 \mathrm{~min}$ (bottom), $30 \mathrm{~min}$ (middle), and $120 \mathrm{~min}$ (top) after adding the substrates.

Order of reference of DNA spots: 1, L. pneumophila GIFU $9134^{\mathrm{T}} ; 2$, L. bozemanii GIFU 9140 $; 3$, L. dumoffii GIFU 9244 ${ }^{\mathrm{T}} ; 4$, L. feeleii GIFU $10063^{\mathrm{T}} ; 5$, L. anisa GIFU $11198^{\mathrm{T}}$; 6, L. gormanii GIFU $9142^{\mathrm{T}} ; 7$, L. spiritensis GIFU $11199^{\mathrm{T}}$.

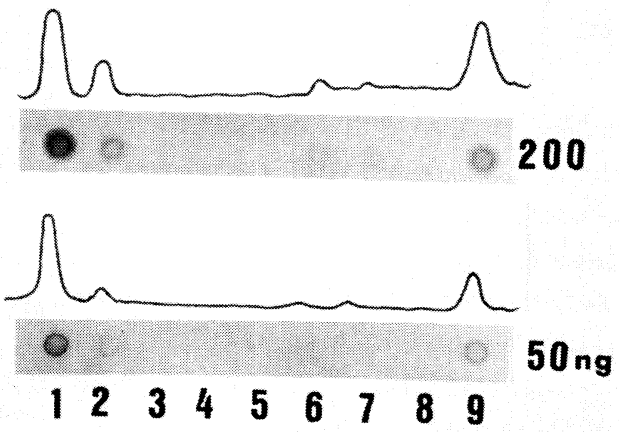

Fig. 4. Identification of serologically unidentified strains of legionellae by quantitative dot hybridization.

The environmental strain GIFU 10023 was labeled. The incubation for enzyme reaction was stopped within $60 \mathrm{~min}$ after adding the substrates. Fifty nanograms and $200 \mathrm{ng}$ of reference DNA spots were quantified with a color graphic analyzer.

Order of reference DNAs from No. 1 to No. 7 is as in Fig. 3. No. 8 is the DNA of calf thymus. The No. 9 spot is the DNA of GIFU 10023.

The other type strains listed in Table 1 did not cross-hybridized with this GIFU 10023 strain. The other 19 environmental strains listed in Table 2 hybridized strongly with $L$. pneumophila GIFU 9134. 
for small clinical laboratories. To evaluate hybridization results without a color graphic analyzer, we prepared four different DNA spots of each reference strain. When several DNA spots of $200 \mathrm{ng}$ were cross-hybridized, their lower DNA spots, 100,50 , or $25 \mathrm{ng}$ were compared with each other. The genetically closely related species could be differentiated by this method without help of a color graphic analyzer.

The amount of labeled DNA required for the quantitative dot hybridization usually could be extracted from a single colony from a primary isolation plate. Nitrocellulose filters spotted with reference DNAs could be stored for several months. Thus, when required, the dot hybridization method would be carried out immediately.

We believe this method would be applicable for routine identification of Legionella species at many bacteriology laboratories if reference DNA filters become supplied commercially.

\section{REFERENCES}

1) D. J. Brenner, A. G. Steigerwalt, G. W. Gorman, H. W. Wilkinson, W. F. Bibb, M. Hackel, R. L. Tyndall, J. Campbell, J. C. Feeley, W. L. Thacker, P. Skaliy, W. T. Martin, B. J. Brake, B. S. Fields, H. V. McEachern, and L. K. Corcoran, Int. J. Syst. Bacteriol., 35, 50 (1985).

2) A. C. Forster, J. L. Mcinnes, D. C. Skingle, and R. H. Symons, Nucl. Acids Res., 13, 745 (1985).

3) M. RenZ and C. KurZ, Nucl. Acids Res., 12, 3435 (1984).

4) T. Ezaki, N. Yamamoto, K. Ninomiya, S. SuZuki, and E. Yabuuchi, Int. J. Syst. Bacteriol., 33, 683 (1983).

5) J. J. Leary, D. J. Brigati, and D. C. Ward, Proc. Natl. Acad. Sci. U.S.A., 80, 4045 (1983).

6) H. W. Wilkinson, J. S. Sampson, and B. B. Plikaytis, J. Clin. Microbiol, 23, 217 (1986).

7) P. H. Edelstein, J. Clin. Microbiol., 23, 481 (1986). 